\title{
Keterlibatan Manajemen Pengetahuan dan Manajemen Bakat Pada Kinerja Karyawan di PT Ditoeku
}

\author{
Roymon Panjaitan \\ Universitas Sains dan Teknologi Komputer, Semarang \\ roymon@stekom.ac.id
}

\begin{abstract}
The purpose of this research study is to mitigate the participation of knowledge management and talent management in improving employee performance. The selection of quantitative methods used from the number of respondents amounted to 55 employees of PT Ditoeku. Data collection techniques with the dissemination of questionnaires, interviews, and literature study support. Descriptive analysis and linear regression for further hypothesis development. Research shows that knowledge management factors have significant positive implications in some employees and talent management has a significant positive effect on employees. This correlation relationship has two positive contributions, the first of which practically implies on the managerial of the company that can directly improve the performance of employees of employee talent, both real knowledge management can improve employee performance that impacts the individual and for the company. Thus, simultaneously there is a positive relationship between knowledge management and talent management for optimization of employee performance.
\end{abstract}

Keyword Knowledge Management, Talent Management, Employee Performance

\section{PENDAHULUAN}

Perkembangan yang terus meningkat di dalam persaingan global tentu akan membuat perusahaan-perusahaan yang sudah ada akan mendapat tekanan untuk dapat beradaptasi sesuai dengan kondisi lingkungan bisnis saat ini. Oleh karena itu perusahaan dituntut untuk meningkatkan usahanya dengan cara memaksimalkan dan memperbaharui tujuan perusahaannya. Hal ini diharapkan dapat membuat perusahaan bisa terus bertahan dalam dunia bisnis. Menurut Ratnasari, (2017) kinerja dapat diukur dari hasil kualitas dan kuantitas kerja yang dicapai. Kinerja karyawan yang optimal merupakan modal perusahaan untuk dapat mencapai tujuannya,sehingga perusahaan perlu memerhatikan faktor-faktor yang dapat mempengaruhi kinerja karyawan.

Kinerja karyawan yang baik dapat dilihat dari kualitas, kuantitas dan ketepatan waktu karyawan dalam menyelesaikan tugasnya berdasarkan standar yang telah ditentukan. Edi, Moeheriono Si, (2012) menjelaskan bahwa keutamaan dari kinerja itu sendiri terdapat pada hasil apa yang diterima (output) dari fungsi-fungsi suat pekerjaan dan manfaat yang telah dkeluarkan (outcame). Seperti yang telah dikatakan oleh Moeheriono, bahwa output yang dihasilkan merupakan faktor yang menentukan kinerja 
maka berikut data penjualan dari PT. Ditoeku selama 4 bulan terakhir yang penulis dapatkan.

Tabel 1. Analisa target bulanan 2021

\begin{tabular}{ccc}
\hline No. & Bulan & Value (Rp) \\
\hline 1. & Januari & 7.999 .211 .627 \\
2. & Februari & 7.712 .834 .766 \\
3. & Maret & 5.256 .761 .175 \\
4. & April & 7.724 .453 .880 \\
\hline
\end{tabular}

Sumber : Data target bulanan PT. Ditoeku

Tabel di atas menunjukkan hasil penjualan yang dilakukan PT Ditoeku selama 4 bulan terakhir sempat mengalami penurunan pada bulan maret sebesar $24,6 \%$. Hal tersebut dikarenakan karyawan PT Ditoeku belum bekerja cukup optimal untuk mencapai target yang diberikan perusahaan Sehingga dapat dikatakan bahwa penurunan tingkat kinerja karyawan dapat memberikan dampak negatif berupa penurunan keuntungan perusahaan. Salah satu faktor yang terkait dengan upaya meningkatkan kinerja sumberdaya manusia adalah berkenaan dengan manajemen pengetahuan dimana beberapa studi terdahulu menunjukkan bahwa manajemen pengetahuan mampu mempengaruhi kinerja pegawai (Nisa et al., 2016). (Anggoro et al., 2017) menjelaskan bahwa dengan penciptaan, penyimpanan, penyebaran dan penerapan pengetahuan merupakan upaya untuk membangun kualitas dari kekayaan intelektual yang dimiliki sehingga dapat mencapai tujuan organisasi atau dengan nama lainnya manajemen pengetahuan.

Sebuah organisasi di United States yang bernama Delphi Consulting Group mengatakan hasil risetnya bahwa persebaran pengetahuan atau knowledge dalam organisasi, $12 \%$ berupa knowledge base elektronik, 26\% pada dokumen kertas, $20 \%$ pada dokumen elektronik, dan terbanyak $42 \%$ tersimpan dan terstruktur di pikiran atau otak karyawan (Harmen, 2018; Latief et al., 2019). Maka dapat dikatakan pengetahuan telah menjadi pengaruh yang penting dalam proses meningkatkan kinerja karyawan. Hal ini didukung dengan hasil penelitian (Nisa et al., 2016); (Wijayanti \& Sundiman, 2017); (Kardo et al., 2020). Selain pengetahuan faktor lain yang dapat mempengaruhi kinerja karyawan yaitu manajemen talenta.

Menurut Octavia, (2018) menjelaskani bahwa adanya hubungan yang signifikan antara manajemen talenta dengan kinerja karyawan dapat dilihat ketika suatu perusahaan yang melakukan investasi berupa manajemen talenta dapat menghasilkan pekerjan yang berkualitas dan nmenghasilkan karya dengan kualitas kinerja yang tinggi. Sejalan dengan pengertian manajemen talenta menurut (Garavan et al., 2012) yang menyatakan bahwa, talent management berhubungan dengan mencari orang yang tepat untuk disposisi yang tepat sesuai dengan keterampilan.

Salah satu manfaat dari pelaksanaan program manajemen talenta adalah tersedianya terus menerus karyawan yang mencapai potensi terbaik mereka masingmasing dan meningkatkan kinerja yang ada dalam institusi atau perusahaan.

Penelitian yang dilakukan oleh Siagian, L. (2020) menemukan bahwa manajemen talenta berada pada kategori kuat pada kinerja karyawan. Dari hasil penelitian manajemen talenta memiliki pengaruh signifikan pada kinerja karyawan, sehingga apabila 
manajemen talenta ditingkatkan maka akan terjadi peningkatan kinerja karyawan. Hal ini sejalan dengan penelitian yang dilakukan oleh (Darmawan et al., 2016); (Fatmasari, 2017); (Maya \& Thamilselvan, 2013).

Sementara itu penelitian yang dilakukan oleh (Saleh, 2020) menunjukkan bahwa tidak ada faktor besar manajemen bakat secara parsial pada kepuasan kerja atau hasil. Tujuan penelitian ini adalah untuk mengidentifikasi efek manajemen pengetahuan dan manajemen bakat secara parsial dan bersamaan pada efisiensi karyawan.

\section{LANDASAN TEORI}

\section{Manajemen Pengetahuan}

Stimulus bagi karyawan dalam manajemen pengetahuan bagi setiap individu memberikan keyakinan dan nilai-nilai yang dianut dan asumsi yang mendasarinya, dan mengungkapkan dampaknya pada penciptaan, berbagi, dan penerapan pengetahuan yang dapat mempengaruhi kinerja organisasi secara keseluruhan (Al Saifi, 2015). Kemampuan mengembangkan pengetahuan lewat teknologi informasi meningkatkan kemampuan manajemen pengetahuan dan dinamika lingkungan secara positif dikaitkan dengan ambidexterity inovasi. Maka hal ini sangat penting dalam pengembangan informasi melalui inovasi informasi yang terintegrasi ke dalam suatu sistem (Soto-Acosta et al., 2018); (Abualoush et al., 2016).

\section{Manajemen Bakat}

(Khoreva et al., 2017; Mensah, 2019) secara praktis praktik manajemen bakat (TM) berdampak pada komitmen karyawan potensial tinggi terhadap pengembangan kompetensi kepemimpinan. Selain itu praktik manajemen bakat tidak hanya memiliki efek positif langsung, tetapi juga efek tidak langsung pada hasil karyawan berbakat. Di masa depan, membangun tenaga kerja tidak hanya membutuhkan perekrutan dan penanaman bakat baru yang diperlukan, tetapi juga keterampilan ulang pekerja saat ini melalui program pelatihan dan mendesain ulang proses pekerjaan untuk mengurangi kurangnya keahlian antara pekerjaan dan karyawan.. Model bisnis baru memberlakukan persyaratan keterampilan digital baru untuk tenaga kerja demi keberlanjutan dan keunggulan kompetitif perusahaan (Karacay, 2018); (Whysall et al., 2019)

\section{Kinerja Karyawan}

Peningkatan lingkungan kerja dalam semua aspek termasuk lingkungan fisik, emosional, dan kepemimpinan yang efektif bagi rekan - rekan kerja memberikan hasil hubungan positif ikut terlibat secara sehat di setiap pekerjaan mereka (Pawar \& Pawar, 2019). Faktor lain keterlibatan karyawan dapat dipengaruhi oleh beberapa faktor : faktor organisasi (gaya manajemen, hadiah pekerjaan, dll.), faktor pekerjaan (lingkungan kerja, karakteristik tugas, dll.) dan faktor individu (energi fisik, kesadaran diri) (Sun \& Bunchapattanasakda, 2019). Perusahaan secara langsung harus mampu mencurahkan sumber daya yang signifikan untuk membuat survei keterlibatan karyawan dan evaluasi dalam bentuk pelatihan untuk mengukur kepuasan (Tanwar, 2017); (Sharma \& Taneja, 2018).

\section{METODOLOGI PENELITIAN}

Penelitian ini dilakukan pada PT Ditoeku Jawa Tengah. Jumlah populasi dalam studi ini tidak lebih dari 100 orang, yaitu berjumlah 55 orang. Hal ini sesuai sejalan dengan 
pendapat Arikunto, (2012, 2017) mengatakan jika jumlah populasinya kurang dari 100 orang, maka jumlah sampelnya diambil secara keseluruhan, tetapi jika populasinya lebih besar dari 100 orang, maka bisa diambil 10-15\%atau 20$25 \%$ dari jumlah populasinya. Adapun yang menjadi variabel dependen yaitu variabel Y sebagai kinerja karyawan dan variabel bebas terdiri dari X1 = Manajemen pengetahuan dan (X2) manajemen talenta. Definisi operasional dalam parameter penelitian ini yaitu manajemen pengetahuan, manajemen talenta dan kinerja karyawan. Indikator dalam manajemen pengetahuan yaitu people, process dan technology. Variabel manajemen talenta (X2) merupakan sumber daya manusia yang memiliki bakat guna sebagai investasi bagi perusahaan di masa yang akan datang. Indikator manajemen talenta yaitu orientation, retain dan developing. Sedangkan variabel (Y) kinerja karyawan merupakan hasil suatu pekerjaan yang dihasilkan oleh karyawan kurun waktu tertentu. Indikator variabel ini yaitu quality, quantity, cooperation, responsibility dan initiatives. Berikut kerangka pemikiran dalam studi ini :

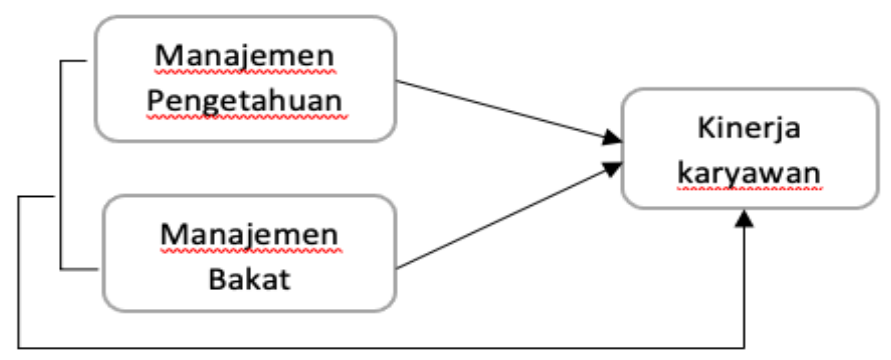

Gambar 1 : Kerangka konseptual

Teknik pengumpulan data yang digunakan dalam penelitian ini berupa kuesioner. Kuesioner sendiri memiliki arti sejumlah pertanyaan atau pernyataan tertulis kepada responden untuk dijawabnya, (Sugiyono, 2014). Di dalam kuesioner akan terdapat daftar pernyataan mengenai persepsi responden tentang manajemen pengetahuan, manajemen talenta, dan kinerja karyawan. Sedangkan untuk pengukurannya penulis berpedoman dengan skala likert dengan ketentuan Sangat setuju bobot nilai 5, setuju bobot nilai 4, ragu - ragu bobot nilai 3 , tidak setuju nilai 2 , sangat tidak setuju nilai 1 .

\section{Uji Asumsi Klasik}

Uji normalitas bertujuan untuk mengetahui bentuk distribusi data apakah data terdistribusi normal atau tidak. Untuk mengetahui hasil uji ini dapat dilihat dari analisis statistik dan grafik distribusi. Dalam grafik distribusi data yang terdistribusi normal akan membentuk satu garis lurus diagonal, dan garis yang menggambarkan data akan mengikuti garis diagonalnya. Sedangkan uji norrmalitas menggunakan uji statistik SPSS Kolmogorov-Smirnov dengan pedoman sebagai berikut :

1. Jika probabilitas $>0,05$ maka distribusi dari model regresi adalah normal.

2. Jika probabilitas $<0,05$ maka distribusi dari model regresi adalah tidak normal.

\section{Uji Multikolinearitas}

Salah satu asumsi dari model regresi linier bahwa tidak terjadi korelasi yang signifikan antara variabel bebasnya. Untuk menguji hal tersebut maka diperlukan 
suatu uji yang disebut uji multikolinieritas. Untuk mengetahui hasil uji dan uji multikolinearitas dapat dilihat beberapa cara yaitu :

1. Dengan melihat nilai tolerance

a. Apabila nilai tolerancenya sendiri lebih besar dari 0,10 maka dapat disimpulkan tidak terjadi multikolinearitas

b. Sedangkan bila nilai tolerancenya lebih kecil dari 0,10 maka kesimpulan yang didapat adalah terjadi multikolinearitas.

2. Dengan melihat nilai VIF

a. Jika nilai VIF lebih dari 10, maka kita akan mendapat kesimpulan bahwa data yang kita uji tersebut memiliki multikolinearitas.

b. Sedangkan jika nilai VIF dibawah 10, maka kita akan mendapat kesimpulan bawa data yang kita uji tidak memiliki multikolinearitas.

\section{Uji Heterokedastisitas}

(Ghozali, 2008) mengatakan bahwa uji heteroskedastisitas bertujuan untuk mengetahui apakah dalam sebuah model regresi terjadi ketidaksamaan varian dari residual suatu pengamatan ke pengamatan lain. Adapun pedoman dalam menentukan hasil uji heterokedastisitas menurut Ghozali yaitu :

1. Apabila titik-titik yang tersebar membentuk suatu pola yang teratur (bergelombang, melebar kemudian menyempit) maka telah terjadi heteroskedastisitas. Jika tidak ada yang jelas serta titik-titik menyebar diatas dan dibawah angka nol pada sumbu Y maka tidak terjadi heteroskedastisitas.

\section{Uji Autokorelasi}

Uji autokolerasi yang dilakukan penelitian ini bertujuan untuk mengetahui apakah dalam sebuah model regresi linier ada kolerasi antara kesalahan penganggu pada periode $t$ dengan kesalahan pada periode $\mathrm{t}-1$ (sebelumnya). Untuk mengetahui ada atau tidaknya otokorelasi dilakukan uji Durbin-Watson dengan Keputusan sebagai berikut :

1. Jika $(\mathrm{D}-\mathrm{W})<1 \mathrm{~d}$, maka ho ditolak (terjadi autokolerasi)

2. Jika $(\mathrm{D}-\mathrm{W})>\mathrm{u}$ d, maka ho diterima (tidak terjadi autokolerasi)

3. Jika $1 \mathrm{~d}<(\mathrm{D}-\mathrm{W})<\mathrm{u} d$, maka tidak dapat diambil kesimpulan

\section{Analisis Regresi Linear Berganda}

Analisis regresi linear berganda merupakan perluasan dari regresi linear sederhana. Tujuannya yaitu untuk mengetahui besarnya pengaruh dari variabel independent terhadap variabel dependen. Dalam penelitian ini model regresi yang digunakan adalah analisis regresi linear berganda dengan bentuk persamaan:

$$
\mathrm{Y}=\mathrm{a}+\mathrm{b}_{1} \cdot \mathrm{X}_{1}+\mathrm{b}_{2} \cdot \mathrm{X}_{2}+\mathrm{e}
$$

Keterangan :

$\mathrm{Y}=$ nilai $\mathrm{Y}$ prediksi, $\mathrm{X}_{1}=$ Variabel bebas, $\mathrm{X}_{2}=$ Variabel bebas, $\mathrm{b}_{1}=$ Koefisien variabel bebas, $\mathrm{b}_{2}=$ Koefisien variabel bebas dan $\mathrm{e}=$ Kesalahan Prediksi (error)

\section{Uji Hipotesis}

1. Uji parsial digunakan pada uji t menunjukkan seberapa jauh pengaruh suatu variabel independen secara individual dalam menerangkan variabel dependen. Penerimaan atau 
penolakan hipotesis dilakukan dengan kriteria $\mathrm{H}_{0}$ ditolak jika $\mathrm{t}_{\text {hitung }}>\mathrm{t}$ tabel atau nilai sig $<0,05$ dan $\mathrm{H}_{0}$ diterima jika $\mathrm{t}_{\text {hitung }}<\mathrm{t}_{\text {tabel }}$ atau nilai sig $>0,05$. Uji F secara simultan perlu dilakukan untuk megetahui pengaruh semua variabel independent yang terdapat di dalam model secara simultan terhadap variabel dependen. Hasil perhitungan yang diperoleh dengan menggunakan tingkat resiko atau signifikan level 5\% atau dengan degree freedom $=\mathrm{k}(\mathrm{n}-\mathrm{k}-1)$ dengan kriteria sebagai berikut :

2. $\mathrm{H}_{0}$ ditolak jika $\mathrm{F}_{\text {hitung }}>\mathrm{F}_{\text {tabel }}$ atau nilai sig $<\alpha$

3. $\mathrm{H}_{0}$ diterima jika $\mathrm{F}_{\text {hitung }}<\mathrm{F}_{\text {tabel }}$ atau nilai sig $>\alpha$

\section{Koefisien Determinasi $\mathbf{R}_{2}$}

Menurut Ghozali (2016:98), untuk mengukur seberapa jauh kemampuan variabel independen dalam menerangkan variasi variabel dependen dapat digunakan uji koefisien determinan. Adapun kriteria untuk pengambilan keputusan yaitu, jika nilai R Square mendeteksi nol (0), maka pengaruh variabel independen pada variabel dependen lemah.

\section{HASIL PENELITIAN}

\section{Uji Normalitas}

Uji normalitas bertujuan untuk mengetahui bentuk distribusi data apakah data terdistribusi normal atau tidak. Untuk mengetahui hasil uji ini dapat dilihat dari analisis statistik dan grafik distribusi. Dalam penelitian ini berikut hasil perhitungan menggunakan SPSS 20.0

Tabel 2 . Uji Normalitas

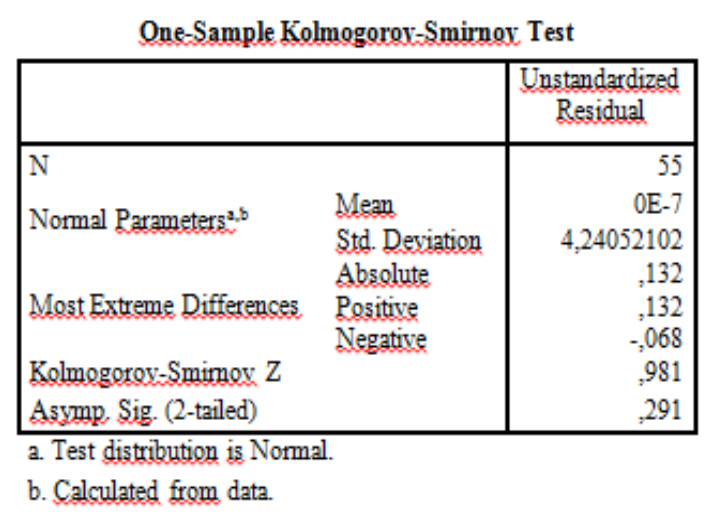

Sumber : data diolah 2021

Berdasarkan hasil uji formalitas di atas menunjukkan bahwa besar nilai dari uji normalitas Kolmogorov-Smirnov adalah 0,981 dan signifikansi pada 0,291 maka dapat disimpulkan data terdistribusi secara normal karena Asymp, Sig. sebesar 0,291 yang berarti lebih besar dari pada nilai signifikansi $0,05(0,291>0,05)$. Hasil ini juga didukung dengan hasil analisis grafik normal p-plot.

\section{Uji Multikolinearitas}

Uji multikolinearitas bertujuan untuk mengetahui bahwa tidak terjadi korelasi yang signifikan antara variabel bebasnya. 
Tabel 4. Hasil Uji Multikolinearitas

\begin{tabular}{lllll}
\multicolumn{5}{c}{ Coefficientsa } \\
\cline { 3 - 5 } Model & \multicolumn{3}{c}{ Collinearity Statistics } \\
\cline { 3 - 5 } & & Tolerance & VIF \\
\hline & (Constant) & & 805 & 1,243 \\
& X1 & &, 805 & 1,243 \\
\hline
\end{tabular}

Sumber : data diproses SPSS (2021)

Hasil pengujian di atas diketahui nilai tolerance variabel Manajemen pengetahuan (X1) dan manajemen talenta (X2) sebesar 0,805 yang berarti dari kedua variabel tersebut memiliki nilai yang lebih besar dari 0,10 sedangkan nilai Value Inflation Factor (VIF) kedua variabel tersebut sebesar 1,243 yang artinya < 10. Maka dapat disimpulkan pada model regresi ini tidak terjadi multikolinearitas antara variabel bebas.

\section{Uji Heterokedastisitas}

Uji heteroskedastisitas bertujuan untuk mengetahui apakah dalam sebuah model regresi terjadi ketidaksamaan varian dari residual suatu pengamatan ke pengamatan lain. Berikut hasil pengujian menggunakan SPSS 20.0

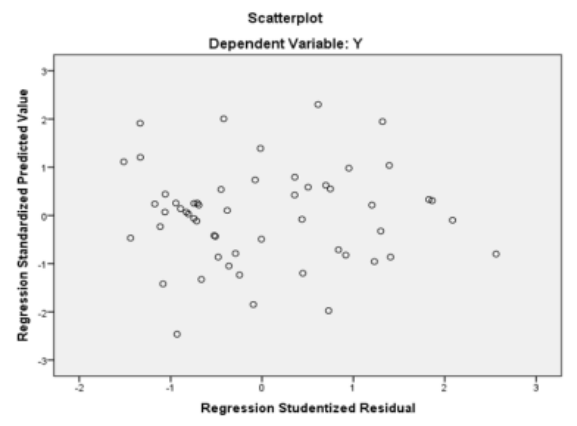

Gambar 3. Grafik Uji Heterokedastisitas Sumber : data diproses SPSS (2021)

Berdasarkan grafik scatterplot (gambar X Uji Heterokedastisitas) di atas menjelaskan bahwa titik-titik menyebar secara acak tidak membentuk suatu pola dan tersebar diatas dan dibawah angka 0 (nol) pada sumbu Y, maka dapat disimpulkan bahwa tidak terjadi heterokedastisitas pada model regresi ini.

\section{Uji Autokorelasi}

Bertujuan untuk mengetahui dalam sebuah model regresi linier ada indikasi korelasi antara kesalahan pengganngu pada periode $t$ dengan kesalahan pada periode $t$ dengan kesalahan pada paeriode t-1 (sebelumnya). Berikut hasil olah data dari SPSS 20.0

Tabel 5. Hasil Uji Durbin Watson

\begin{tabular}{cc}
\hline Model & $\begin{array}{c}\text { Durbin } \\
\text { Watson }\end{array}$ \\
\hline 1 & 1,861 \\
\hline
\end{tabular}

Sumber : data diproses SPSS (2021) 
Hasil dari pengujian durbin watson diketahui nilai DW 1,861 sedangkan nilai dl dan du (dilihat dari tabel Durbin -watson) untuk $\mathrm{n}=55$ dan $\mathrm{k}=2$ didapatkan masingmasing 1,4903 dan 1,6406 sehingga keputusan yang didapat DW > du, maka Ho diterima atau tidak terjadi autokorelasi positif. Selain itu nilai $(4-\mathrm{dw})$ sebesar 2,139> du yang berarti tidak terjadi auto kolerasi negatif. Maka dapat disimpulkan tidak terdapat autokorelasi positif maupun autokorelasi negatif pada model regresi ini.

\section{Analisis Regresi Linear Berganda}

Analisis regresi linier berganda digunakan untuk mengetahui pengaruh antara variabel Manajemen Pengetahuan $\left(\mathrm{X}_{1}\right)$ dan Manajemen Talenta $\left(\mathrm{X}_{2}\right)$ terhadap kinerja karyawan (Y). Berdasarkan hasil perhitungan diperoleh persamaan regresi sebagai berikut :

Tabel 6. Hasil Regresi Linear Berganda

Coefficients $^{\mathrm{a}}$

\begin{tabular}{llrr}
\hline Model & & \multicolumn{3}{c}{ Unstandardized Coefficients } \\
\cline { 3 - 4 } & & \multicolumn{2}{c}{ Std. Error } \\
\cline { 3 - 4 } & (Constant) & 32,038 & 6,364 \\
1 & X1 &, 450 &, 184 \\
& X2 &, 248 &, 105 \\
\hline a. & Dependent Variable: Y & &
\end{tabular}

Sumber : data diproses SPSS (2021)

Hasil koefisien regresi linier berganda memperlihatkan nilai koefisien konstanta sebesar 32,038 secara matematis menyatakan bahwa jika nilai variabel $\mathrm{X}_{1}$ (Manajemen pengetahuan) dan $\mathrm{X}_{2}$ (Manajemen talenta) sama dengan nol maka nilai $\mathrm{Y}$ adalah 32,038. Koefisien regresi variabel manajemen pengetahuan sebesar 1 skor dengan asumsi variabel $\mathrm{X}_{2}$ manajemen talenta tetap maka akan menyebabkan kenaikan kinerja karyawan sebesar 0,450 Koefisien regresi variabel $\mathrm{X}_{2}$ (Manajemen talenta) sebesar 0,248. Artinya bahwa tiap meningkat $\mathrm{X}_{2}$ (Manajemen talenta) sebesar 1 skor dengan asumsi variabel $\mathrm{X}_{1}$ (manajemen pengetahuan) tetap maka akan menyebabkan kenaikan kinerja karyawan sebesar 0,248

\section{Uji Hipotesis}

Uji t merupakan uji parsial yang bertujuan untuk menunjukkan seberapa jauh pengaruh suatu variabel independent secra individual dalam menerangkan variabel independen. Berikut hasil pengujian uji t menggunakan SPSS 20.0

\begin{tabular}{|c|c|c|c|}
\hline \multicolumn{4}{|c|}{ Tabel 7. Hasil Uji T } \\
\hline & & $\mathrm{t}$ & Sig. \\
\hline & (Constant) & 5,034 & ,000 \\
\hline 1 & $\mathrm{X} 1$ & 2,450 & 018 \\
\hline & $\mathrm{X} 2$ & 2,362 & ,022 \\
\hline
\end{tabular}

Sumber : data diproses SPSS (2021)

Berdasarkan tabel 59 di atas terdapat beberapa keputusan yaitu :

Secara parsial variabel $\mathrm{X}_{1}$ (manajemen pengetahuan) memiliki pengaruh positif dan signifikan terhadap variabel Y (kinerja karyawan). Hal ini dijelaskan dari hasil 
perhitungan bahwa nilai $t_{\text {hitung }} 2,450>t_{\text {tabel }} 2,006$ dan signifikan $(0,018)<$ nilai $\alpha(0,05)$, maka kesimpulannya tolak $\mathrm{H}_{0}$ terima $\mathrm{H}_{1}$ yang berarti terdapat pengaruh positif dan signifikan antara manajemen pengetahuan terhadap kinerja karyawan. Secara parsial variabel $\mathrm{X}_{2}$ (manajemen talenta) memiliki pengaruh positif dan signifikan terhadap variabel Y (kinerja karyawan). Hal ini dijelaskan dari hasil perhitungan bahwa nilai thitung $2,362>\mathrm{t}_{\text {tabel }} 2,006$ dan signifikan $(0,022)<$ nilai $\alpha(0,05)$, maka kesimpulannya tolak $\mathrm{H}_{0}$ terima $\mathrm{H}_{2}$ yang berarti terdapat pengaruh positif dan signifikan antara manajemen talenta terhadap kinerja karyawan.

\section{Uji F (Simultan)}

Uji $F$ ini dilakukan untuk mengetahui pengaruh semua variabel independen yang terdapat di dalam model secara bersama-sama (simultan) terhadap variabel dependen. Berikut hasil pengujiannya menggunakan SPSS 20.0

Tabel 8. Hasil Uji F

\begin{tabular}{|c|c|c|c|}
\hline & & & \\
\hline Model & & $\mathrm{F}$ & Sig. \\
\hline \multirow{3}{*}{1} & $\underline{\text { Regression }}$ & 10,373 &, $000^{\mathrm{b}}$ \\
\hline & Residual & & \\
\hline & Total & & \\
\hline
\end{tabular}

Sumber : data diproses SPSS (2021)

Berdasarkan tabel di atas diketahui $\mathrm{X}_{1}$ (manajemen pengetahuan), $\mathrm{X}_{2}$ (manajemen talenta) dan $\mathrm{Y}$ (kinerja karyawan) memiliki $\mathrm{F}_{\text {hitung }} 10,373>\mathrm{F}_{\text {tabel }}$ 3,18 dan nilai signifikan sebesar $0,000<0,05$ yang artinya bahwa $X_{1}$ (manajemen pengetahuan) dan $X_{2}$ (manajemen talenta) secara bersama-sama (simultan) berpengaruh signifikan terhadap $\mathrm{Y}$ (kinerja karyawan). Maka $\mathrm{H}_{0}$ ditolak $\mathrm{H}_{3}$ diterima.

\section{Koefisien Determinasi $\mathbf{R}_{2}$}

Uji koefisien determinasi bertujuan untuk mengukur seberapa jauh kemampuan model dalam menerangkan variasi variabel dependen. Nilai koefisien determinasi adalah antara nol dan satu. Berikut hasil pengujian menggunakan SPSS 20.0

Tabel 9. Uji Koefisien Determinasi

\begin{tabular}{|c|c|c|}
\hline & Model Sun & \\
\hline Model & $\mathrm{R}$ & R Square \\
\hline 1 &, $534^{\mathrm{a}}$ & 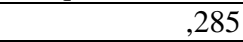 \\
\hline
\end{tabular}

Berdasarkan tabel di atas dapat diketahui bahwa besarnya Adjusted $\left(\mathrm{R}^{2}\right)$ sebesar 0,285 hal ini memiliki arti bahwa $28 \%$ variabel kinerja karyawan dapat dipengaruhi oleh variabel kedua yaitu variabel independen (manajemen pengetahuan dan manajemen talenta) sedangkan sisanya $(100 \%-28 \%=72 \%)$ dipengaruhi oleh faktor-faktor lain yang artinya $72 \%$ secara bebas berpengaruh terhadap variabel lainnya yang tidak diuji didalam tabel. 


\section{PEMBAHASAN}

\section{Pengaruh Manajemen Pengetahuan terhadap Kinerja Karyawan}

Berdasarkan hasil penelitian yang telah dilakukan penulis, bahwa manajemen pengetahuan berpengaruh positif dan signifikan terhadap kinerja karyawan Hal ini sejalan dengan penelitian yang dilakukan Hilma Harmen dimana manajemen pengetahuan sebagai faktor yang dimiliki tiap individu yang dapat mempengaruhi kinerja karyawan. Selain itu hasil penelitian yang dilakukan oleh (Zargar \& Rezaee, 2013) juga berpendapat bahwa penggunaan manajemen pengetahuan merupakan komponen integral dari organisasi yang memiliki kegunaan untuk meningkatkan pengetahuan dan informasi karyawan sehingga akan meningkatkan produktivitas karyawan. Dalam penelitian (Monsow et al., 2018); (Karuri \& Nahashon, 2015); (Alyoubi et al., 2018) juga menyebutkan bahwa manajemen pengetahuan berpengaruh positif terhadap kinerja karyawan.

\section{Pengaruh Manajemen Talenta terhadap Kinerja Karyawan}

Hasil penelitian yang dilakukan menemukan bahwa manajemen talenta berpengaruh positif dan signifikan terhadap kinerja karyawan Sesuai dengan penelitian yang dilakukan (Bibi, 2018) menyimpulkan bahwa hubungan antara perekrutan, pelatihan, dan pengembangan bakat terhadap kinerja karyawan secara statistik signifikan. Selain itu (Knott, 2016) juga menyatakan bahwa pelatihan dan pengembangan merupakan komponen penting strategi manajemen bakat organisasi yang dapat meningkatkan kinerja karyawan. Adapun penelitian (Kardo et al., 2020; Rachmadinata \& Ayuningtias, 2017) mengatakan bahwa adanya pengaruh positif dan signifikan manajemen talenta terhadap kinerja karyawan.

\section{Pengaruh Manajemen Pengetahuan dan Manajemen Talenta terhadap Kinerja Karyawan}

Berdasarkan hasil uji simultan $\mathrm{F}$ maka dapat diperoleh hasil bahwa variabel manajemen engetahuan dan manajemen talenta memiliki pengaruh yang positif dan signifikan secara bersama-sama terhadap variabel kinerja karyawan. Hasil ini didukung dengan penelitian terdahulu yang dilakukan oleh (Kardo et al., 2020) dimana semakin tinggi manajemen pengetahuan dan manejemen talenta dimiliki perusahaan maka semakin baik pula kedua variabel mempengaruhi kinerja perusahaan.

Hasil penelitian ini menunjukan bahwa seluruh hipotesis yang diajukan dalam penelitian ini dapat diterima, dan dinyatakan terdapat pegaruh positif dan signifikan antara manajemen pengetahuan, manajemen talenta terhadap kinerja karyawan PT Ditoeku. hasil penelitian ini sejalan dengan penelitian yang dilakukan oleh (Harmen, 2018) mengatakan faktor pertama yang mempengaruhi kinerja karyawan adalah faktor individu yang didalamnya termasuk talenta dan pengetahuan yang dimiliki individu sejak lahir. Adapun penelitian (Rizki Anugrah, 2019); (Pusriadi \& Darma, 2020);(Wibowo et al., 2017) juga mengatakan bahwa manajemen pengetahuan dan manajementalenta memiliki pengaruh positif dan signifikan terhadap kinerja karyawan.

\section{KESIMPULAN}

Dari hasil olah data terdapat 2 kontribusi positif yang dihasilkan dari hubungan manajemen pengetahuan pada kinerja karyawan, artinya indikator penanda seperti manusia, proses dan teknologi berfungsi mengoptimalkan kinerja karyawan. Begitu juga 
jalnya dengan penanda dari pengemabangan yang dimiliki melalui soft skill dan hard skill secara positif berkontribusi terhadap optimalisasi kinerja karyawan pada perusahaan. Hal lain juga lebih penting dari studi ini manajemen bakat dan pengetahuan terbukti secara implikatif bila dilakukan secara simultan berdampak positif pada kinerja karyawan. Implikasi positif dalam hasil studi ini data terbagi menjadi dua. Pertama, implikasi bagi karyawan tentunya dengan adanya manejemen pengetahuan semua bentuk pekerjaan yang membutuhkan sumber tenaga, proses pekerjaan dan adopsi teknologi membuat tugas dan karyawan memiliki wawasan luas tentang proses bekerja secara efektif melalui proses adaptasi teknologi. Kedua implikasi bagi manajerial tentunya manajer PT Ditoeku dapat mengarahkan bakat setiap individu sesuai dengan keahliannya sesuai dengan potensi yang dimiliki karyawan. Maka implikasi kedua ini menjadi sumber daya yang penting dan optimal untuk menciptakan keunggulan bersaing bagi nilai perusahaan maupun stimulus bagi karyawan untuk terus termotivasi dalam kinerja bagi perusahaan.

\section{SARAN}

Saran bagi pihak manajerial PT Ditoeku dipertukaran informasi khusus kepada karyawannya seperti portal khusus untuk mencari informasi terkini mengenai perkembangan teknologi. Hal penting lain, PT Ditoeku dapat melakukan promosi jabatan kepada para karyawannya agar terus lebih termotivasi memberikan hasil terbaiknya dalam bekerja. Peneliti juga menyarankan perusahaan untuk tetap mengembangkan manjemen lain seperti manajemen waktu, manajemen resiko dan efektivitas manajemen pemasaran untuk selalu terlibat dalam kemajuan profit perusahaan. Keterbatasan dalam penelitian ini hanya meneliti di satu perusahaan, maka untuk peneliti selanjutnya dapat memperluas variabel lain seperti kapabilitas inovasi, ketangakasan adaptasi teknologi pada ketahanan usaha.

\section{DAFTAR PUSTAKA}

Abualoush, S. H., Obeidat, A. M., Masa'deh, R., \& Al-Badi, A. (2016). The role of Employees' Empowerment as an intermediary variable between Knowledge Management and Information Systems on Employees' Performance. VINE Journal of Information and Knowledge Management Systems.

Al Saifi, S. A. (2015). Positioning organisational culture in knowledge management research. Journal of Knowledge Management. https://doi.org/10.1108/JKM-072014-0287

Alyoubi, B., Hoque, M. R., Alharbi, I., Alyoubi, A., \& Almazmomi, N. (2018). Impact of Knowledge Management on Employee Work Performance: Evidence from Saudi Arabia. The International Technology Management Review. https://doi.org/10.2991/itmr.7.1.2

Anggoro, B. K., Hubeis, M., \& Sailah, I. (2017). Identifikasi Model Manajemen Pengetahuan. Jurnal Ilmu Pendidikan.

Bibi, M. (2018). Impact of Talent Management Practices on Employee Performance. SEISENSE Journal of Management. https://doi.org/10.33215/sjom.v2i1.83

Darmawan, A. S., Hamid, D., \& Mukzam, M. D. (2016). PENGARUH MOTIVASI KERJA DAN KEMAMPUAN KERJA TERHADAP KINERJA KARYAWAN (Studi pada Karyawan PT. PLN (Persero) Distribusi Jawa Timur Area Malang). Jurnal Administrasi Bisnis S1 Universitas Brawijaya. 
Edi, Moeheriono Si, D. M. (2012). Pengukuran Kinerja Berbasis Kompetensi. In Jakarta: Raja Grafindo Persada.

Fatmasari. (2017). Pengaruh Talent Management dan Self Efficacy Terhadap Kinerja Karyawan. Jurnal Bisnis Darmajaya, Vol.03. No.02, Juli 2017.

Garavan, T. N., Nilsson, S., \& Ellström, P. (2012). Employability and talent management: Challenges for HRD practices. European Journal of Training and Development. https://doi.org/10.1108/03090591211192610

Ghozali, I. (2008). SEM Metode Alternatif dengan PLS. In Semarang : Badan Penerbit Universitas Diponegoro.

Harmen, H. (2018). Pengaruh Talent Management dan Knowledge Management Terhadap Kinerja Karyawan PT. Perkebunan Nusantara II (Survei Pada Kantor Direksi Tanjung Morawa). JKBM (JURNAL KONSEP BISNIS DAN MANAJEMEN). https://doi.org/10.31289/jkbm.v4i2.1587

Karacay, G. (2018). Talent Development for Industry 4.0. https://doi.org/10.1007/978-3319-57870-5_7

Kardo, K., Wilujeng, S., \& Suryaningtyas, D. (2020). PENGARUH MANAJEMEN TALENTA DAN MANAJEMEN PENGETAHUAN TERHADAP KINERJA KARYAWAN DI TRANSFORMER CENTER KABUPATEN BATU. Jurnal Riset Mahasiswa Manajemen. https://doi.org/10.21067/jrmm.v6i1.4466

Karuri, M., \& Nahashon, L. (2015). Effect on talent management on employee outcomes: A case study on central bank of Kenya. The Strategic Journal of Business and Change Mangement.

Khoreva, V., Vaiman, V., \& Van Zalk, M. (2017). Talent management practice effectiveness: investigating employee perspective. Employee Relations. https://doi.org/10.1108/ER-01-2016-0005

Knott, E. (2016). The Effect of Talent Management Practices on Employee Performance Among Real Estate Companies in Kenya: A Case of Suraya Property Group Limited. In Scinzer Journal of Accounting and Management.

Latief, A., Nurlina, N., Medagri, E., \& Suharyanto, A. (2019). Pengaruh Manajemen Pengetahuan, Keterampilan dan Sikap terhadap Kinerja Karyawan. JUPIIS: JURNAL PENDIDIKAN ILMU-ILMU SOSIAL. https://doi.org/10.24114/jupiis.v11i2.12608

Maya, M., \& Thamilselvan, R. (2013). Impact of talent management on employee performance and organistional effeciency in itsp's- with reference to chennai city. International Journal of Economic Research.

Mensah, J. K. (2019). Talent Management and Employee Outcomes: A Psychological Contract Fulfilment Perspective. Public Organization Review. https://doi.org/10.1007/s11115-018-0407-9

Monsow, E., Runtuwene, R., \& Rumawas, W. (2018). PENGARUH KNOWLEDGE MANAGEMENT TERHADAP KINERJA KARYAWAN DI BANK MAYAPADA KCU MEGA MAS MANADO. Jurnal Administrasi Bisnis. https://doi.org/10.35797/jab.6.001.2018.18955.

Nisa, R. C., Astuti, E. S., \& Prasetya, A. (2016). Pengaruh Manajemen Talenta dan Manajamen Pengetahuan Terhadap Kinerja Karyawan (Studi pada Karyawan PT. PLN (Persero) Distribusi Jawa Timur, Surabaya). Jurnal Administrasi Bisnis.

Octavia, H. V. (2018). PENGARUH MANAJEMEN TALENTA TERHADAP KINERJA KARYAWAN (Studi Pada Karyawan PT Pertamina Geothermal Energy 
Area Ulubelu). Jurnal Administrasi Bisnis.

Pawar, B. S., \& Pawar, B. S. (2019). Employee performance. In Employee Performance and Well-being. https://doi.org/10.4324/9780429244193-2

Pusriadi, T., \& Darma, D. C. (2020). PENGARUH TALENT MANAGEMENT DAN EMPLOYEE ENGAGEMENT TERHADAP EMPLOYEE CAPABILITIES: STUDI PADA KARYAWAN PT. BINTANG WAHANA TATA. Jurnal Riset Entrepreneurship. https://doi.org/10.30587/jre.v3i1.1317

Rachmadinata, N. S., \& Ayuningtias, H. G. (2017). PENGARUH MANAJEMEN TALENTA TERHADAP KINERJA KARYAWAN LINTASARTA KOTA JAKARTA. Jurnal Manajemen Indonesia. https://doi.org/10.25124/jmi.v17i3.1156

Ratnasari, K. C. K. R. T. (2017). Evaluasi Kinerja Sumber Daya Manusia. In Evaluasi Kinerja Sumber Daya Manusia.

Rizki Anugrah, C. M. (2019). Kajian Penerapan Manajemen Talenta dalam Rangka Mengoptimalkan Kinerja Sumber Daya Manusia pada Bank Bri Kantor Cabang Sukabumi Kantor Wilayah Bandung. Digital Economic, Management and Accounting Knowledge Development (DEMAnD). https://doi.org/10.46757/demand.v1i1.61

Saleh, C. (2020). Pengaruh Kompensasi Melalui Kepuasan Serta Dampaknya Terhadap Kinerja Pegawai Negeri Sipil. J-MKLI (Jurnal Manajemen Dan Kearifan Lokal Indonesia). https://doi.org/10.26805/jmkli.v4i2.110

Sharma, S., \& Taneja, M. (2018). The effect of training on employee performance. International Journal of Recent Technology and Engineering. https://doi.org/10.31104/jsab.v2i2.49

Soto-Acosta, P., Popa, S., \& Martinez-Conesa, I. (2018). Information technology, knowledge management and environmental dynamism as drivers of innovation ambidexterity: a study in SMEs. Journal of Knowledge Management. https://doi.org/10.1108/JKM-10-2017-0448

Sugiyono. (2014). Metode dan Prosedur Penelitian. E-Journal.

Sun, L., \& Bunchapattanasakda, C. (2019). Employee Engagement: A Literature Review. International Journal of Human Resource Studies. https://doi.org/10.5296/ijhrs.v9i1.14167

Tanwar, A. (2017). Impact of Employee Engagement on Performance. International Journal of Advanced Engineering, Management and Science. https://doi.org/10.24001/ijaems.3.5.16

Whysall, Z., Owtram, M., \& Brittain, S. (2019). The new talent management challenges of Industry 4.0. Journal of Management Development. https://doi.org/10.1108/JMD06-2018-0181

Wibowo, F. A., Buana, Y., \& Kurniawan, Y. J. (2017). Analisis Pengaruh Talent Management Terhadap Organizational Performance Dan Dampaknya Pada Employee Retention. Jurnal Administrasi Dan Kesekretarisan.

Wijayanti, D. P., \& Sundiman, D. (2017). Pengaruh Knowledge Management Terhadap Kinerja Karyawan (Studi Empiris Pada Pt. Sms Kabupaten Kotawaringin Timur). DeReMa Jurnal Manajemen.

Zargar, E., \& Rezaee, M. (2013). The Study of Knowledge Management Effect on Performance Rate of Employees. European Online Journal of Natural and Social Sciences. 